
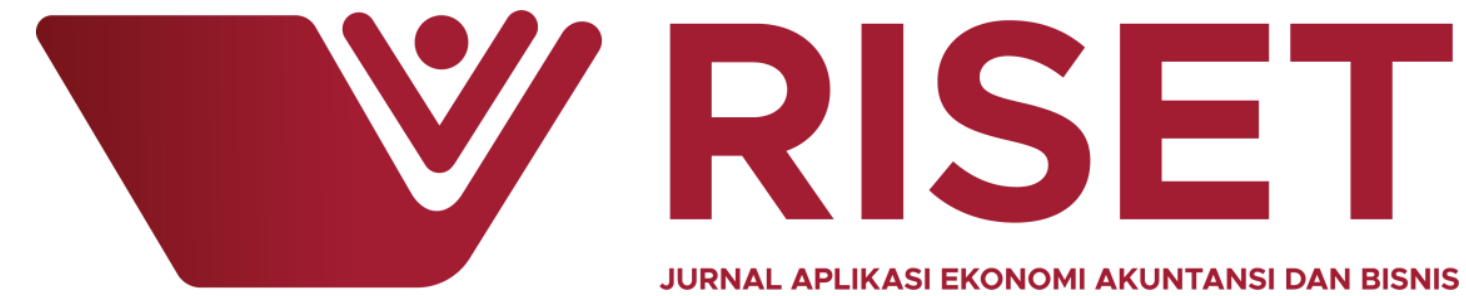

JURNAL APLIKASI EKONOMI AKUNTANSI DAN BISNIS

\title{
ANALISIS BENEISH RATIO INDEX UNTUK MENDETEKSI FRAUDULENT FINANCIAL REPORTING PADA PERUSAHAAN PERBANKAN YANG TERDAFTAR DI BURSA EFEK INDONESIA PERIODE 2015-2016
}

\author{
Indarti Indarti \\ Universitas Lancang Kuning Pekanbaru
}

https://doi.org/10.35212/277625

\section{INFO ARTIKEL}

Analisis Beneish Ratio Index Untuk

Mendeteksi Fraudulent Financial Reporting Pada Perusahaan Perbankan Yang Terdaftar Di Bursa Efek Indonesia Periode 2015-2016

Submitted:

23 JANUARI 2019

Revised:

15 FEBRUARI 2019

Accepted:

10 MARET 2019

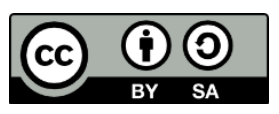

\begin{abstract}
This study aims to determine the percentage of Banking in Indonesia Stock Exchange listed 2015-201 were classified as non manipulators and manipulators.

The object of this study is all Banking companies listed in Indonesia Stock Exchange to publish audited financial statements for the financial year 2015 to 2016. The sampling technique is by using purposive sampling where the sample is determined based on certain criteria specified by the author and have limitations in terms of generalization, Methods of data collection using the method of documentation.

Data analysze technique used is quantitative descriptive analysis using Beneish Ratio Index. The variable in this study is the Days' Sales In Receivables Index (dsri), Gross Margin Index (GMI), Asset Quality Index (AQI), Sales Growth Index (SGI), and Total Accruals To Total Assets Index (TATA).

The research result is an index analysis showed that the ratio of 2 (two) or 7,41\% of the company samples classified as Manipulators. Companies that belong to the category of companies Manipulators have indications commit fraud (fraud) to the presentation of financial statements. Ratio index analysis showed that 16 (sixteen) companies, or 59,26\% of the company samples classified as Non Manipulators. Companies belonging to the company Non Manipulators do not have any indication of fraud (fraud) against the not categorize of financial statement presentation as well as the company Manipulators Non company entered in the class of Grey / Grey Company, this group amounted to 9 companies or 33,33 \% of companies sampled.
\end{abstract}

Keywords: Manipulators, Non Manipulators, Beneish Ratio Index

Email: indarti.sam9@gmail.com 


\section{PENDAHULUAN}

\section{Analisis Situasi}

Secara umum penerbitan laporan keuangan bertujuan untuk memberikan informasi mengenai posisi keuangan, kinerja dan aruskas perusahaan. Pelaporan keuangan bermanfaat bagi sebagian besar kalangan pengguna laporan dalam rangka membuat keputusan-keputusan ekonomi serta menunjukkan pertanggungjawaban manajemen ataspenggunaan sumbersumber daya yang dipercayakan kepada mereka (Ikatan Akuntasi Indonesia, 2007). Oleh karena itu pelaku bisnis harus dapat memberikaninformasi yang akurat dan relevan serta terbebas dari adanya kecurangan (fraud) yang akan sangat menyesatkan parapengguna laporan keuangan dalam proses pengambilan keputusan. Kecurangan (fraud) merupakan suatu tindakan yang dilakukan secara disengaja dan itu dilakukan untuk tujuan pribadi atau orang lain, dimana tindakan tersebut adalah telah menyebabkan kerugian bagi pihak tertentu atau institusi tertentu. Kecurangan ini merupakan suatu tindakan yang sudah berada diluar koridor prinsip akuntansi yang berlaku umum. Kecurangan mencakup tindakan illegalyang sengaja dilakukan, lalu disembunyikan, dan memperoleh manfaat dengan melakukan pengubahan bentuk menjadi uang kas atau barang berharga lainnya. Tindakan ini dilakukanbaik secara internal maupun eksternal, secara sengaja, dan disembunyikan.

A. Terjadinya kecurangan yang tidak dapat terdeteksi, dapat memberikan efek yang merugikan dan cacat bagi proses pelaporan keuangan. Adanya kecurangan berakibat serius dan membawa banyak kerugian. Konsekuensinya adalah deteksi terhadap kecurangan menjadi isu penting. Kemampuan untuk melakukan identifikasi kecurangan secara cepat menjadi suatu kebutuhan. Namun pendeteksian terhadap financial statement fraud tidak selalu mendapatkan titik terang karena berbagai motivasi yang mendasarinya serta banyaknya metode untuk menilai adanyakecurangan tersebut. Menurut teori Cressey (dikutip oleh (Hall \& Singleton, 2007), terdapat tiga kondisi yang selalu hadir dalam tindakan fraudyaitu pressure, opportunity, dan razionalization. Ketiga kondisi tersebutmerupakan faktor risiko munculnya kecurangan dalam berbagai situasi. Dalam artikelnya "The Detection D. Beneish, melakukan penelitian terhadap perbedaan kuantitatif antara of Earnings Manipulation" (Beneish, 1999) Messod perusahaan publik yang melakukan manipulasi laporan keuangan dan perusahaan yang tidak melakukannya. Beneish menggunakan data laporan keuangan dariseluruh perusahaan yang terdaftar dalam COMPUSTAT database tahun 1989-1992. Beneish mengindikasikan bahwa kemungkinan terjadinya manipulasi ditandai dengan peningkatan yang luar biasa pada receivables, memburuknya gross margin, penurunan aktiva, pertumbuhan penjualan, serta meningkatnya accruals.Beneish menggunakan variabel Days' Sales In Receivables Index (DSRI), Gross Margin Index (GMI), Asset Quality Index (AQI), Sales Growth Index (SGI), Depreciation Index (DEPI), Sales General And Administrative Expenses Index (SGAI), Leverage Index (LVGI), danTotal Accruals To Total Assets Index (TATA), sebagai prediktor untuk mendeteksi adanya manipulasi. Dengan menggunakan variabel-variabel tersebut, Beneish mampu mengidentifikasi bahwa $76 \%$ dari perusahaan sampel melakukan manipulasi terhadap laporan keuangannya. Beneish juga menyatakan bahwa variabel DSRI, GMI, AQI, SGI, dan TATA merupakan variabel-variabel yang signifikan dalam mendeteksi kemungkinan adanya manipulasi serta mampu membedakan antara perusahaan manipulator dan perusahaan non manipulator. 
B. Rumusan Masalah

Berdasarkan identifikasi masalah dan pembatasan masalah diatas maka rumusan masalah dalam penelitian ini adalah:

1). Perusahaan mana sajakah yang termasuk dalam kategori melakukan kecurangan dalam pelaporan keuangan dengan menggunakan aplikasi Beneish Ratio Indeks pada perusahaan manufaktur yang listing di Bursa Efek Indonesia tahun 20132015.

2). Perusahaan mana sajakah yang tidak termasuk dalam kategori melakukan kecurangan dalam pelaporan keuangan dengan menggunakan aplikasi Beneish Ratio Indeks pada perusahaan manufaktur yang listing di Bursa Efek Indonesia tahun 2013-2015.

C. Tujuan Penelitian

Tujuan yang ingin dicapai dalam penelitian ini adalah:

a). Untuk menganalisis dan menguji perusahaan mana saja yang melakukan kecurangan dalam pelaporan keuangan dengan menggunakan aplikasi Beneish Ratio Indeks pada perusahaan manufaktur yang listing di Bursa Efek Indonesia tahun 2014-2015.

b). Untuk menganalisis dan menguji perusahaan mana saja yang tidak melakukan kecurangan pada pelaporan keuangan dengan menggunakan aplikasi Beneish Ratio Indeks pada perusahaan manufaktur yang listing di Bursa Efek Indonesia tahun 2014-2015.

Target Luaran:

Adapun yang menjadi target luaran pada penelitian ini adalah :

- Buku Ajar

- Jurnal

- Prosiding

\section{TINJAUAN PUSTAKA}

\section{Kajian Teori}

1). Kecurangan (Fraud)

Dalam Oxford English Dictionary, kecurangan (fraud) adalah sebuah tindak pidana kecurangan dengan menggunakan penyajian yang palsu untuk memperoleh keuntungan dengan cara yang tidak adilatau mengambil paksa hak atau kepentingan orang lain. Menurut Association of Certified Fraud Examiners (ACFE) kecurangan (fraud) didefinisikan sebagai tindakan penipuan atau kekeliruan yang dibuat oleh seseorang atau badan yang mengetahui bahwa kekeliruan tersebut dapat mengakibatkan beberapa manfaat yang tidak baik kepada individu atau entitas atau pihak lain. Menurut ACFE ini, kecurangan merupakan segala sesuatu yang secara lihai dapat digunakan untuk mendapat keuntungan dengan cara menutupi kebenaran, tipu daya, kelicikan atau mengelabui, dan cara yang tidak jujur lainnya. (Bologna \& Lindquist, Robert J.Wells, 1993) seperti dikutip Ratna Wardhani (2012) mendefinisikan kecurangan sebagai: "Fraud is criminal deception intended to financially benefit the deceiver" yaitu kecurangan adalah penipuan kriminal yang bermaksud untuk memberi manfaat keuangan kepada sipenipu. 


\section{Deteksi Kecurangan Laporan Keuangan}

Salah satu risiko yang dihadapi perusahaan adalah integrity risk, yaitu risiko adanya kecurangan oleh manajemen atau pegawai perusahaan, tindakan illegal, atau tindakan penyimpangan lainnya yang dapat mengurangi nama baik/reputasi perusahaan di dunia usaha, atau dapat mengurangi kemampuan perusahaan dalam mempertahankan kelangsungan hidupnya. Adanya risiko tersebut mengharuskan adanya tindakan pencegahan/prevention untuk menangkal terjadinya kecurangan (fraud). Namun pencegahan saja tidaklah memadai, harus dipahami cara mendeteksi secara dini terjadinya kecurangankecurangan yang timbul. Seorang profesor akuntansi, W. Steve Albrecht dalam (Wells, 2011) mengatakan: "Financial statements tell a story and the story should make sense." If not, it's possible the story is a fake. By standing far enough back from the numbers to get a good pictureof the client's business, auditors frequently can detect signs of financial statement frauds. Because the balance sheet, income statement and statement of cash flows are interrelated, such frauds can pop out when certain numbers don't make sense. The inescapable logicof the accounting equation ensures that any major overstatement of assets or profits, will show up over time. Sebagian besar bukti-bukti kecurangan merupakan bukti-bukti yang sifatnya tidak langsung.

Dalam artikelnya "The Detection of Earnings Manipulation" (Beneish, 1999), menteorikan bahwa ada beberapa prediktor dari manipulasi laporan keuangan yang dapat digunakan. Beneish Ratio Index yang digunakan untuk mendeteksi adanya manipulasi dalam laporan keuangan tersebut antara lain:

\section{1). Days Sales in Receivables Index (DSRI)}

Variabel ini mengukur apakah piutang dan pendapatan seimbang atau tidak (out of balance) dalam dua tahun yang berurutan

$$
\text { DSRI }=\frac{(\text { Account Receivable } t / \text { Sales } t)}{(\text { Account Receivable } t-1 / \text { Sales } t-1)}
$$

Keterangan:

$\mathrm{t}=$ Periode awal

$\mathrm{t}-1=$ Periode sebelumnya

Peningkatan jumlah hari penjualan dalam piutang dapat diartikan sebagai hasil dari perubahan kebijakan kredit untuk memacu penjualan dalam menghadapi persaingan yang meningkat. Namun peningkatan piutang dengan cara yang tidak tepat dapat menurunkan penghasilan. Selanjutnya peningkatan DSRI berkaitan dengan tingginya penghasilan dan tingginya earnings karena terjadi overstated.

\section{2). Gross Margin Index (GMI)}

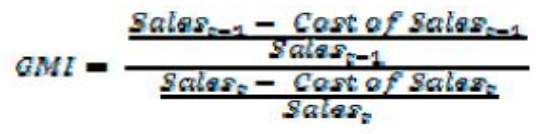

Keterangan:

Sales : Penjualan

Cost of Good Sold : Harga Pokok Penjualan

$\mathrm{t} \quad$ : periode $\mathrm{t}$

$\mathrm{t}-1 \quad$ : Periode tahun sebelumnya

Jika GMI lebih dari 1 (satu), maka terjadi penurunan pada gross margin dan bukti adanya sinyal buruk atas perusahaan. Kenaikan GMI mengindikasikan perusahaan untuk menggelembungkan laba. Dengan demikian terdapat hubungan positif antara GMI dan probabilitas terjadinya manipulasi jika kinerja perusahaan menurun. 


\section{3). Asset Quality Index (AQI)}

$\mathrm{AQI}=$ (1-Current Assets $\mathrm{t}+$ Net fixed Assets $\mathrm{t} /$ Total Assets t $)$ (1-Current Assets t-1 + Net fixed Assets t-1 / Total Assets t-1)

Keterangan:

Current Assets = Aktiva Lancar

Net Fixed Asset $=$ Aktiva Tetap

Total Assets = Total Aktiva

$\mathrm{T} \quad$ = periode $\mathrm{t}$

$\mathrm{t}-1 \quad=$ periode $\mathrm{t}-1$

AQI mengukur risiko dari assets pada tahun $t$ terhadap tahun $t-1$. Jika AQI lebih besar dari 1 (satu), ini mengindikasikan bahwa perusahaan telah secara potensial meningkatkan pengendalian biaya. AQI juga mengukur proporsi dari Total Assets terhadap keuntungan masadepan manakah yang secara potensial kurang pasti. Akibatnya AQI memiliki hubungan positif dengan kemungkinan terjadinya manipulasi dalam laporan keuangan.

\section{4). Sales Growth Index (SGI)}

\section{SGI $=\underline{\text { Sales t }}$}

Sales t-1

Keterangan:

Sales = Penjualan

$\mathrm{T}=$ periode $\mathrm{t}$

$\mathrm{t}-1 \quad=$ periode $\mathrm{t}-1$

SGI dapat memberitahu manakah perusahaan yang memasukkan penjualan palsu. Peningkatan dalam SGI menunjukkan bahwa terdapat kecenderungan perusahaan melakukan pencatatan pendapatan fiktif untuk mempertimbangkan pertumbuhan normalyang diharapkanpada periode tersebut. Meskipun pertumbuhan tidak mengindikasikan adanya manipulasi, namun pertumbuhan yang diikuti dengan penurunan harga saham akan mendorong perusahaan melakukan manipulasi.

\section{5). Depreciation Index (DEPI)}

(Beneish, 1999) memperkirakan terdapat hubungan positif antara DEPI dengan kemungkinan terjadinya manipulasi.

DEPI $=\underline{(\text { Depreciation } /(\text { Depreciation }+ \text { PPE })) t-1}$

Depreciation / (Depreciation + PPE)) $t$

Keterangan:

Depreciation $=$ Depresiasi

PPE (Plant, Property, Equipment $)=$ Aktiva Tetap

$\mathrm{T}=$ periode $\mathrm{t}$

$\mathrm{t}-1 \quad=$ periode $\mathrm{t}-1$

Jika DEPI lebih besar dari 1 (satu), mengindikasikan bahwa tingkat dimana aset sedang didepresiasi melambat, yang meningkatkan kemungkinan bahwa perusahaantelah menaikkan estimasi assets useful lives atau menerapkan metodebaru yaitu peningkatan income.

6). Sales General and Administrative Expenses Index (SGAI)

$$
\text { SGAI }=\frac{(\text { SGA Expense } / \text { Sales }) t}{(\text { SGA Expense } / \text { Sales }) t-1}
$$

Keterangan:

SGA (Sales General and Administrative) Expense = Biaya penjualan administrasi

Sales = Penjualan

$\mathrm{T}=$ periode $\mathrm{t}$

$\mathrm{t}-1=$ periode $\mathrm{t}-1$ 
SGAI menginterpretasikan bahwa peningkatan yang tidak proporsional dalam penjualan sebagai suatu tanda negatif terhadap prospek perusahaan di masa mendatang. (Beneish, 1999) memperkirakan terdapat hubungan positif antara SGAI dengan kemungkinan terjadinya manipulasi.

\section{7). Everage Index (LVGI)}

$$
\text { LVGI }=\frac{((\text { Long Term Debt }+ \text { Current Liabilities }) / \text { Total Assets }) \mathrm{t}}{((\text { Long Term Debt }+ \text { Current Liabilities }) / \text { Total Assets }) \mathrm{t}-1}
$$

Keterangan:

Long Term Debt $=$ Hutang Jangka Panjang

Current Liabilities $=$ Hutang Lancar

Total Assets = Total Aktiva

$\mathrm{t} \quad=$ periode $\mathrm{t}$

$\mathrm{t}-1 \quad=$ periode $\mathrm{t}-1$

LVGI yang lebih besar dari 1 (satu), mengindikasikan peningkatan dalam leverage. Variabel ini dimaksudkan untuk menangkap adanya insentif dalam debt covenant yang digunakan untuk memanipulasi pendapatan. Menurut (Beneish, 1999) perubahan leverage dalam struktur modal sebuah perusahaan dikaitkan dengan pengaruh technical default di bursa saham.

8). Total Accruals to Total Assets (TATA)

TATA $=\triangle \quad$ Working Cap $\Delta$ al $-\triangle$ Cash - Current Taxes Payable - Depreciation and Ammortitation

\section{Total Asset}

Working Capital $=$ Current Assets - Current Liabilities

Keterangan:

$\Delta$ Working Capital $\quad=$ Perubahan Modal Kerja

$\Delta$ Cash $\quad=$ Perubahan Kas

$\Delta$ Current Taxes Payable $\quad=$ Perubahan Piutang pajak

Depreciation and Amortization $=$ Depresiasi dan Amortisasi

Total Assets $\quad=$ Total Aktiva

Current Assets $\quad=$ Aktiva Lancar

Current Liabilities $\quad=$ Hutang Lancar

\section{Tujuan dan manfaat penelitian}

Tujuan Penelitian

Adapun yang menjadi tujuan penelitian ini adalah

a). Untuk menganalisis dan menguji perusahaan mana saja yang melakukan kecurangan dalam pelaporan keuangan dengan menggunakan aplikasi Beneish Ratio Indeks pada perusahaan manufaktur yang listing di Bursa Efek Indonesia tahun 2014-2015.

b). Untuk menganalisis dan menguji perusahaan mana saja yang tidak melakukan kecurangan pada pelaporan keuangan dengan menggunakan aplikasi Beneish Ratio Indeks pada perusahaan manufaktur yang listing di Bursa Efek Indonesia tahun 2014-2015.

\section{Manfaat Penelitian}

Manfaat penelitian ini adalah :

1). Bagi peneliti lain, penelitian ini diharapkan dapat menjadi sumber informasi maupun sebagai bahan referensi bagi yang berminat meneliti lebih jauh tentang bidang yang sama pada masa yang akan datang. 
2). Bagi pemilik perusahaan, hasil penelitian ini diharapkan dapat menjadi pertimbangan nantinya dalam mengambil kebijakan manajemen khusunya yang berkaitan dengan kinerja keuangan.

3). Bagi Investor dapat menjadi bahan masukan sekaligus bahan pertimbangan terhadap pentingnya pelaporan keuangan yang bebas dari terjadinya kecurangan.

4). Bagi Akademisi, dapat dijadikan bahan masukan dalam pengajaran tentang Audit kecurangan atau Fraud Auditing, Audit Forensik dan hal apa saja yang mempengaruhinya.

\section{METODE PENELITIAN}

\section{Desain Penelitian}

Jenis penelitian deskriptif bertujuan untuk menggambarkan sifat sesuatu yang tengah berlangsung pada saat penelitian dilakukan dan memeriksa sebab-sebab dari suatu gejala tertentu. Berdasarkan data yang diperoleh, penelitian ini menggunakan data kuantitatif yaitu datayang berbentuk angka karena mengacu pada perhitungan.

Tempat dan Waktu Penelitian

Penelitian ini dilaksanakan dengan mengambil data laporan keuangan perusahaan perbankan yang listingdi Bursa Efek Indonesia pada tahun 2016. Data diambil dari situs resmi BEI yaitu www.idx.co.id.

\section{Populasi dan Sampel}

1. Populasi

Populasi dalam penelitian adalah seluruh perusahaan perbankan yang telah terdaftar di Bursa Efek Indonesia sebanyak 43 perusahaan. Metode pemilihan sample menggunakan metode purposive sampling yaitu pemilihan sampel berdasarkan tujuan penelitian dengan pertimbangan khusus.

2. Sampel

Adapun kriteria -kriteria dalam pengambilan sampel yaitu:

1). Perusahaan Perbankan yang terdaftar di bursa efek Indonesia berturut - turut selama periode tahun 2016

2). Perusahaan Perbankan yang mempublikasikan laporan keuangan tahunan dalam website perusahaan atau website BEI selama periode 2015-2016 yang dinyatakan dalam rupiah.

3). Perusahaan yang mengalami laba selama periode pengamatan.

4). Perusahaan yang mengungkapkan data - data berkaitan dengan variabel penelitian dan tersedia secara lengkap.

5). Perusahaan yang tidak delisting selama periode pengamatan.

Tabel-1

Teknik Pengambilan Sampel

\begin{tabular}{|l|l|c|}
\hline No & \multicolumn{1}{|c|}{ Keterangan } & Jumlah \\
\hline 1 & $\begin{array}{l}\text { Perusahaan Perbankan yang terdaftar di bursa efek Indonesia } \\
\text { berturut - turut selama periode tahun 2015-2016 }\end{array}$ & 43 \\
\hline 2 & $\begin{array}{l}\text { Perusahaan Perbankan yang mempublikasikan laporan } \\
\text { keuangan tahunan dalam website perusahaan atau website }\end{array}$ & 0 \\
& $\begin{array}{l}\text { BEI selama periode 2015-2016 yang tidak dinyatakan dalam } \\
\text { rupiah. }\end{array}$ & \\
\hline 3 & Perusahaan yang tidak mengalami laba selama periode & 0 \\
\hline
\end{tabular}




\begin{tabular}{|l|l|c|}
\hline & pengamatan. & \\
\hline 4 & $\begin{array}{l}\text { Perusahaan yang tidak mengungkapkan data - data berkaitan } \\
\text { dengan variabel penelitian dan tersedia secara lengkap }\end{array}$ & $(14)$ \\
\hline 5 & Perusahaan yang tidak delisting selama periode pengamatan. & $(2)$ \\
\hline & Total Perusahaan Perbankan yang dijadikan sample & 27 \\
\hline
\end{tabular}

Sumber Data: Data BEI tahun 2016

\section{PEMBAHASAN}

Dari tabel diatas dapat diketahui kriteria penggolongan masingmasing ratio index (indeks hitung). Menentukan perusahaan tergolong manipulators atau non manipulators menurut kriteria penggolongan :

1). Perusahaan yang memiliki $\geq 3$ (tiga) indeks hitung yang sesuai dengan indeks parameter yang menyatakan Manipulators, tergolong ke dalam perusahaan Manipulators.

2). Perusahaan yang memiliki $\geq 3$ (tiga) indeks hitung yang sesuai dengan indeks parameter yang menyatakan Non Manipulators, tergolong ke dalam perusahaan Non Manipulators.

3). Perusahaan yang memiliki $\geq 3$ (tiga) indeks hitung yang sesuai dengan indeks parameter yang menyatakan grey, dan indeks hitung yang tidak memenuhi 2 (dua) kriteria penggolongan tersebut (Manipulatorsdan Non Manipulators) digolongkan perusahaan grey(Grey Company).

Hasil penggolongan perusahaan yang digolongkan terhadap 27 perusahaan disajikan dalam tabel sebagai berikut:

Tabel 2 - Hasil Penggolongan Perusahaan

\begin{tabular}{|c|c|c|c|c|c|c|c|c|c|}
\hline \multirow{28}{*}{$\begin{array}{l}\text { Rangkuman } \\
\text { data }\end{array}$} & No & Code & DSRI & GMI & AQI & SGI & TATA & \multicolumn{2}{|r|}{ Kategori } \\
\hline & 1 & AGRO & G & G & G & G & M & G & Grey \\
\hline & 2 & BABP & M & $\mathrm{N}$ & M & G & M & M & Manipulator \\
\hline & 3 & BACA & $\mathrm{N}$ & $\mathrm{N}$ & $\mathrm{M}$ & $\mathrm{M}$ & $\mathrm{N}$ & $\mathrm{N}$ & Non Manipulator \\
\hline & 4 & BAEK & $\mathrm{N}$ & $\mathrm{G}$ & $\mathrm{N}$ & $\mathrm{N}$ & $\mathrm{M}$ & $\mathrm{N}$ & Non Manipulator \\
\hline & 5 & $\mathrm{BBCA}$ & $\mathrm{N}$ & $\mathrm{G}$ & $\mathrm{M}$ & $\mathrm{G}$ & $\mathrm{N}$ & G & Grey \\
\hline & 6 & BBKP & $\mathrm{N}$ & $\mathrm{N}$ & $\mathrm{N}$ & $\mathrm{G}$ & $\mathrm{M}$ & $\mathrm{N}$ & Non Manipulator \\
\hline & 7 & $\mathrm{BBNI}$ & $\mathrm{G}$ & $\mathrm{N}$ & $\mathrm{G}$ & $\mathrm{N}$ & $\mathrm{N}$ & $\mathrm{N}$ & Non Manipulator \\
\hline & 8 & BBNP & $\mathrm{G}$ & $\mathrm{N}$ & $\mathrm{N}$ & $\mathrm{N}$ & M & $\mathrm{N}$ & Non Manipulator \\
\hline & 9 & BBRI & $\mathrm{N}$ & $\mathrm{N}$ & $\mathrm{N}$ & G & $\mathrm{N}$ & $\mathrm{N}$ & Non Manipulator \\
\hline & 10 & BBTN & $\mathrm{N}$ & M & $\mathrm{N}$ & G & $\mathrm{N}$ & $\mathrm{N}$ & Non Manipulator \\
\hline & 11 & BCIC & $\mathrm{N}$ & $\mathrm{N}$ & $\mathrm{N}$ & $\mathrm{G}$ & $\mathrm{N}$ & $\mathrm{N}$ & Non Manipulator \\
\hline & 12 & BDMN & $\mathrm{N}$ & $\mathrm{G}$ & $\mathrm{M}$ & $\mathrm{G}$ & $\mathrm{G}$ & $\mathrm{G}$ & Grey \\
\hline & 13 & BEKS & $\mathrm{G}$ & $\mathrm{G}$ & $\mathrm{M}$ & $\mathrm{G}$ & $\mathrm{M}$ & $\mathrm{G}$ & Grey \\
\hline & 14 & BKSW & $\mathrm{G}$ & $\mathrm{G}$ & $\mathrm{N}$ & $\mathrm{G}$ & $\mathrm{M}$ & $\mathrm{G}$ & Grey \\
\hline & 15 & BMRI & $\mathrm{N}$ & $\mathrm{N}$ & $\mathrm{N}$ & $\mathrm{N}$ & $\mathrm{G}$ & $\mathrm{N}$ & Non Manipulator \\
\hline & 16 & BNBA & $\mathrm{N}$ & $\mathrm{M}$ & $\mathrm{G}$ & $\mathrm{N}$ & $\mathrm{N}$ & $\mathrm{N}$ & Non Manipulator \\
\hline & 17 & BNII & $\mathrm{M}$ & $\mathrm{M}$ & $\mathrm{M}$ & $\mathrm{N}$ & $\mathrm{N}$ & $\mathrm{M}$ & Manipulator \\
\hline & 18 & BNLI & $\mathrm{N}$ & $\mathrm{N}$ & $\mathrm{N}$ & $\mathrm{N}$ & $\mathrm{N}$ & $\mathrm{N}$ & Non Manipulator \\
\hline & 19 & BSWD & $\mathrm{G}$ & $\mathrm{G}$ & $\mathrm{N}$ & $\mathrm{G}$ & $\mathrm{N}$ & $\mathrm{G}$ & Grey \\
\hline & 20 & BTPN & $\mathrm{N}$ & $\mathrm{G}$ & $\mathrm{N}$ & $\mathrm{G}$ & $\mathrm{N}$ & $\mathrm{N}$ & Non Manipulator \\
\hline & 21 & BVIC & $\mathrm{G}$ & $\mathrm{N}$ & $\mathrm{N}$ & $\mathrm{G}$ & $\mathrm{M}$ & G & Grey \\
\hline & 22 & INPC & $\mathrm{N}$ & $\mathrm{N}$ & $\mathrm{G}$ & $\mathrm{G}$ & $\mathrm{G}$ & $\mathrm{G}$ & Grey \\
\hline & 23 & MAYA & $\mathrm{M}$ & G & $\mathrm{N}$ & $\mathrm{G}$ & $\mathrm{N}$ & G & Grey \\
\hline & 24 & MEGA & $\mathrm{N}$ & $\mathrm{N}$ & $\mathrm{N}$ & G & $\mathrm{N}$ & $\mathrm{N}$ & Non Manipulator \\
\hline & 25 & NISP & $\mathrm{G}$ & $\mathrm{N}$ & $\mathrm{N}$ & $\mathrm{G}$ & $\mathrm{N}$ & $\mathrm{N}$ & Non Manipulator \\
\hline & 26 & PNBN & $\mathrm{M}$ & $\mathrm{N}$ & $\mathrm{N}$ & $\mathrm{N}$ & $\mathrm{M}$ & $\mathrm{N}$ & Non Manipulator \\
\hline & 27 & SDRA & $\mathrm{N}$ & $\mathrm{N}$ & $\mathrm{N}$ & G & M & $\mathrm{N}$ & Non Manipulator \\
\hline
\end{tabular}

Sumber : hasil olahan 


\section{SIMPULAN DAN SARAN}

\section{Simpulan}

Penelitian ini bertujuan untuk mengetahui manakah perusahaan yang tergolong Manipulators dan Non Manipulators dengan membandingkan indeks rasio perusahaan atau indeks hitung dan indeks Beneish sebagai parameter. Indeks rasio yang digunakan adalah Days Sales In Receivables Index (DSRI), Gross Margin Index (GMI), Asset Quality Index (AQI), Sales Growth Index (SGI),danTotal Accruals To Total Assets Index (TATA).

Berdasarkan analisis dan pembahasan yang ada, maka dapat ditarik simpulan sebagai berikut:

1. Perusahaan Manipulators

Analisis indeks rasio menunjukkan bahwa 2 (dua) perusahaan atau 7,4\% perusahaan sampel tergolong sebagai Manipulators. Perusahaan yang tergolong dalam kategori perusahaan Manipulators memiliki indikasi melakukan fraud (kecurangan) terhadap penyajian laporan keuangannya.

2. Perusahaan Non Manipulators

Analisis indeks rasio menunjukkan bahwa 16 (enambelas) perusahaan atau \% perusahaan sampel tergolong sebagai Non Manipulators. Perusahaan yang tergolong dalam perusahaan Non Manipulators memiliki indikasi tidak melakukan fraud (kecurangan) terhadap penyajian laporan keuangannya. Perusahaan yang tidak tergolong sebagai perusahaan Manipulators dan juga sebagai perusahaan Non Manipulators masuk dalam golongan Grey/ Grey Company, perusahaan golongan ini berjumlah 16 perusahaan atau 59,25\% perusahaan sampel.

\section{B. Saran}

Berdasarkan simpulan yang didapat serta keterbatasan penelitian yang ada, saran untuk penelitian selanjutnya adalah peneliti selanjutnya diharapkan dapat memilih periode tahun pengamatan yang lebih panjang, memperluas sampel penelitian, sehingga tidak terbatas hanya pada satu sektor saja, dengan tujuan supaya hasil yang nantinya diperoleh akan lebih akurat sehingga dapat menggambarkan fenomena financial statement fraud. Dalam penelitian selanjutnya dapat menambahkan variabelvariabel akuntansi lain seperti Sales General And Administrative Expenses Index (SGAI), Leverage Index (LVGI), danDepreciation Index (DEPI), yang mungkin dapat melengkapi dan meningkatkan hasil yang lebih baik. Selain itu, penelitian selanjutnya juga dapat menghitung tingkat signifikansi daritiap variabel-variabel akuntansi, sehingga dapat diketahui mana variabel yang secara signifikan mampu membedakan antara perusahaan manipulators dan perusahaan non manipulators.

Bagi perusahaan, diharapkan tidak melakukan kecurangan (fraud) dalam peyajian laporan keuangaannya, karena hal itu dapat merugikan pengguna laporan keuangan tersebut. Bagi investor, calon investor, pernegang saham dan kreditur serta analisis pasar modal dalarn mengambil keputusan untuk membeli saham, diharapkan dapat melakukan analisis dengan baik terhadap laporan keuangan ataupun mencari informasi tambahan di luar laporan keuangan tersebut. 


\section{DAFTAR PUSTAKA}

Beneish, M. D. (1999). The Detection of Earnings Manipulation. Financial Analysts Journal, 55(5), 24-36. https://doi.org/10.2469/faj.v55.n5.2296

Bologna, G. J., \& Lindquist, Robert J.Wells, J. T. (1993). The Accountant's Handbook of Fraud and Commercial Crime (Edisi 1). John Wiley \& Sons.

Hall, J. A., \& Singleton, T. (2007). Audit dan Assurance Teknologi Informasi (edisi 2; Terjemahan Dewi Fitriasari, ed.). Jakarta: Salemba Empat.

Ikatan Akuntasi Indonesia. (2007). Standar Akuntansi Keuangan. Jakarta: Salemba Empat.

Wells, J. T. (2011). Financial Statement Fraud Casebook: Baking the Ledgers and Cooking the Books. John Wiley \& Sons. 
Riset: Jurnal Aplikasi Ekonomi, Akuntansi dan Bisnis Vol. 1 No. 1, April 2019, Hal 057 - 066 